\title{
Minimizing the Impact of Yellowfin Tuna Thunnus albacares fishing in Banda Sea
}

\author{
Haruna $^{1 *}$, Agustinus Tupamahu ${ }^{1}$, and Achmar Mallawa ${ }^{2}$
}

\author{
${ }^{1}$ Fisheries and Marine Science Faculty of Pattimura University, Ambon ,Indonesia \\ *Corresponding author : $\underline{\text { har flash@yahoo.co.id }}$ \\ ${ }^{1}$ Fisheries and Marine Science Faculty of Pattimura University, Ambon ,Indonesia \\ agus.tupamahu@fpik.unpatti.ac.id \\ ${ }^{2}$ Marine Science and Fisheries Faculty of Hasanudin University, Makassar, Indonesia \\ achmarmallawa@yahoo.co.id
}

\begin{abstract}
The declining trend of Yellowfin Tuna Thunnus albacares production in Fishery Management Territory of Indonesia 714 nowadays will affect the demand for tuna products in Indonesia and global. Regarding the management purposes, the impact of fishing needs to be minimized. Therefore, the estimation of population structure based on the length and age is very important to be studied. The data were collected from November 2015 to October 2016 from longline and handline catching activities operated in the Banda Sea. The average length of yellowfin tuna caught with longline and handline was $98.5 \mathrm{~cm}$ and the first length maturity was $L_{m} 103.6 \mathrm{~cm}$. The result showed that the first yellowfin tuna caught was Lc_opt $125.2 \mathrm{~cm}$, where fishing mortality ratio toward natural mortality was at the level that endangered the sustainability ofyellowfin tuna fisheries in the Banda Sea. To minimize the impact, there needs to be a minimum size regulation of yellowfin tuna that should be landed.
\end{abstract}

Keywords- Yellowfin Tuna, First Caught Length, Yield, Biomass, Banda Sea.

\section{INTRODUCTION}

Yellowfin Tuna Thunnus albacares is one of the important commercial big pelagic fish and lives in tropical and subtropical waters (Wu et al., 2010; Collette and Nauen, 1983). Banda Sea is one of the potential tuna fishing areas in Indonesia, the types of fishing gear used consist of purseseine, pole and line, tuna longline, handline and trolling line. The production of tuna in Maluku during the period of 2012 - 2016 has decreased; the average decline was $24.3 \%$. The decrease of the production was caused by the temporary suspension of licensing of catch fishery business in the fisheries management territory of the Republic of Indonesia, especially the purse seine fisheries fleet (Ministry of Fisheries and Marine Affairs Regulation No. 56, 2014), and banning the purseseine systemof two vessels to catch big pelagic fish (Candy KP number 71 , 2016).
The status of yellowfin tuna stocks at Western and Central Pacific Ocean at the end of 2012 is slightly above maximum sustainable yield, and the highest impact of catching occurs in the tropics area (Davies et al, 2014; Brouwer et al, 2016; IOTC, 2018). The impact of high catching in the tropic area is due largely to the catch of yellowfin tuna with purseseine belonging to young fish (Widodo et al, 2015; Brouwer et al, 2016; Haruna et al, 2018).

Overfishing is one form of over-exploitation of fish populations to a dangerous level. The reduction of the fish catch impact of is discussed in international forums such as Rio + 20 summit of June 2012 (UN 2012), and meeting on fish catching that are responsible at international level (FAO 2012). According to Froese et al (2016), minimizing the impact of fishing on a population is closeto-natural figures of individuals should participate in important life history events. There are two important characteristics of the population in fisheries management, i.e. the average duration of the reproduction phase if the total mortality of $\mathrm{Z}=\mathrm{M}+\mathrm{F}$ is fairly constant after the age of the fish reaches maturity, and the average duration of the reproduction phase is the opposite of $\mathrm{Z}$ (Carnov, 1993). There are three options proposed by Froese et.al (2016) regarding the handling of fish populations, the first is fishing mortality is smaller than natural mortality, second is that catch should not reduce the population under half of natural abundance that is not exploited, and the third is the exploited individual population should be allowed to reproduce in order to realize its growth potential before it is captured. Fox (1970) or Schaefer (1954) production model shows that maximum sustainable yield can be obtained on stock sizes between $37 \%$ and $50 \%$ of unexploited biomass. Beverton and Holt (1957) say that the yield per recruit of catch mortality, catch and largest biomass can be obtained by increasing the length of the first time catch. The fact is minimizing the catch impact on biomass and age structure if the allowable catch is approximately the optimum size of the 
individual (about $2 / 3$ of the maximum length, $L \infty$ ) where the biomass cohort is maximum (Froese et al., 2008).

In 7 regions at the Western and Central Pacific Ocean, the highest annual yellowfin tuna recruitment in region 7 (Indonesia, Philippines and Vietnam) are 0.42, the highest catch mortality due to the catch of yellowfin young age with purse seine was in region 3 and fisheries of Indonesia, Philippines, and Vietnam are in region 7 (Davies et al, 2014). According to Damora and Baihaqi (2013), the total length of yellowfin tuna that is first catch with the shelling line in the Banda Sea is $131.85 \mathrm{~cm}$, and the natural mortality and catch mortality are 0.68 and 1.79. Fishing mortality of adult yellowfin tuna in Western and Central Pacific Ocean (WCPO) in 2000 ranged from 0.18 to 0.56 , at Indian Ocean at the highest was 0.2 in 2010, and at WCPO 2010, it ranged from 0.25 to 0.45 (Hampton, 2004; Langley et al., 2011; Langley et al., 2012).

The estimation value of fishing mortality depends on the fishing gear, the method of catching and the distribution of the sampled fish size. The estimation of fishing mortality in Banda Sea by Damora and Baihaqi is only to the fishing gear and the samples which are limited to large fish, while in WCPO and Indian Ocean on purse seine and fishing gear. High catch mortality indicates high fishing pressure on fish stock in a waters. After purse seine of two vessel system is prohibited from the operation to catch tuna fish in all Indonesia Fishery
Management Area including Banda Sea, tuna production depends only on long line and others fishery. Therefore, it is necessary to evaluate the condition of yellowfin tuna stock, in order to obtain the option to minimize the impact of the catch for its sustainability through limitation of the fish size that may be caught.

\section{MATERIALS AND METHODS}

Forked length size data of yellowfin tuna were obtained from tuna fishing activities (long line and hand line) operating in the Banda Sea from November 2015 to October 2016. The collected data were as much as 4,829 individuals of yellowfin tuna. The map of yellowfin tuna fishing operations in the Banda Sea is shown in Fig. 1.

The growth parameter of Von Bertalanffy was estimated by using ELEFAN-I developed completely by Gayanilo Jr. et al. (1996) by projecting some possible combinations of growth parameters of von Bertalanffy ( $\mathrm{L}_{\infty}$ and $K$ ). Growth parameter $\mathrm{t}_{\mathrm{o}}$ is counted according to Pauly (1980) by the equation:

$\log \left(t_{0}\right)=-0.3922-0.2752 \quad\left(\log L_{\infty}\right)-1.038 \quad(\log$ $\mathrm{K}$ ) and natural mortality $(\mathrm{M})$ is estimated by the equation: $\log M=0.0066-0.279 \log L \infty+0.6543+0.4634 \log T$ $\log \mathrm{K}$.

$\begin{array}{lrr}\text { In which } \mathrm{M}=\text { the } & \text { rate } & \text { of natural } \\ \text { mortality / (year) } \mathrm{L}_{\infty}=\text { as ymptotic } & \text { length } & (\mathrm{cm}), \mathrm{K}\end{array}$ = growth rate coefficient $/$ (year), $\mathrm{T}=$ the average of water surface temperature $\left({ }^{\circ} \mathrm{C}\right)=29^{\circ} \mathrm{C}$.

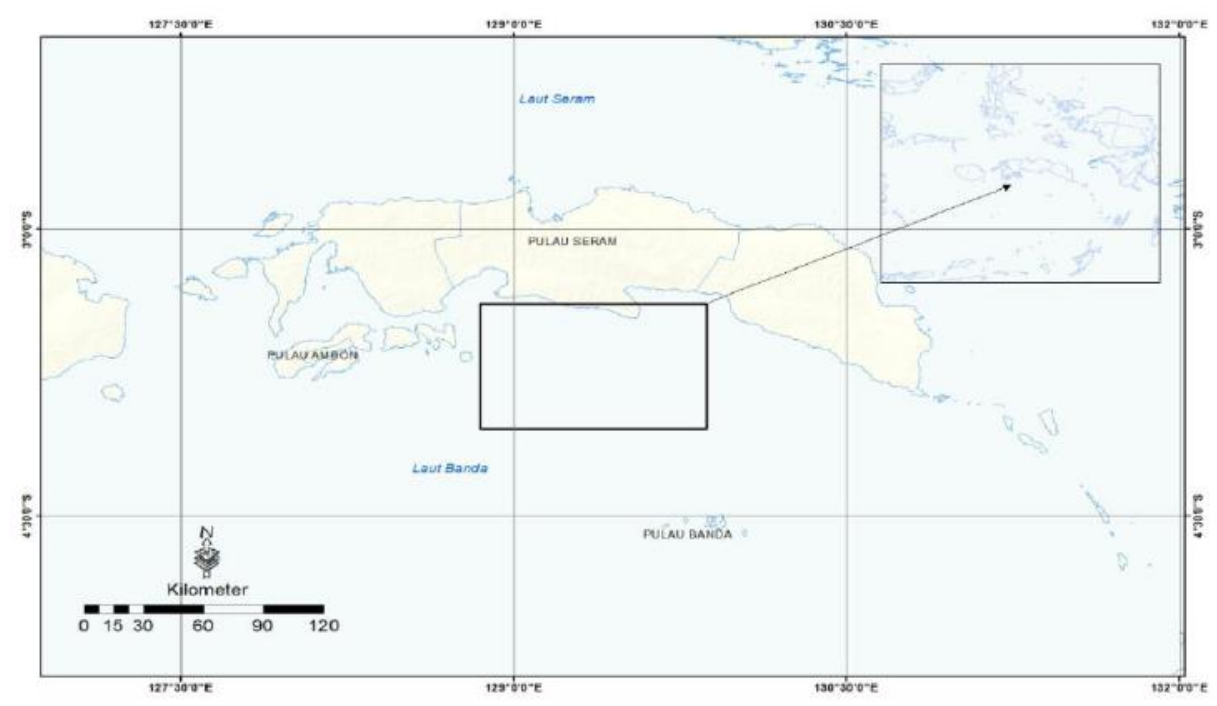

Fig. 1. Map of yellowfin tuna fishing operations in the Banda Sea.

The first size estimation of ripe gonads using the Sperman-Karber method (Udupa, 1986) used two criteria of gonad maturity which were immature group of gonads (Gonad Maturity Level I and II) and mature gonad group (Gonad Maturity Level III, IV and V). The estimation of the average size of gonads first mature fish usedsize group of gonad mature fish (Gonad Maturity Level III and
IV) based on morphological criteria (Itano, 2001) and was analyzed by referring to Sparre and Venema (1989).The length of first catch $\mathrm{L}_{\mathrm{c}_{-} \text {opt }}$ is obtained by the equation (Froese et al., 2016):

$$
L_{\left(c_{-}\right. \text {opt }}=\frac{L_{\infty}(2+3 F / M)}{(1+F / M)(3+M / K)}
$$




In which $\mathrm{M}$ and $\mathrm{F}$ are obtained
from $\mathrm{L}_{\infty}$ and $\mathrm{K}, \mathrm{L}_{\infty}$ and $\mathrm{K}$ are the parameters of von Bertalanffygrowthequation(1938), and the other variables are determined based on various equations thathave been published previouslysuch asFroese (2006), Holt (1958), Beverton(1992), Charnov (1993),Bevertonand Holt (1957) and Holt (1966).

Analysis of minimizing the fishing impact to meet the 3 options of yellowfin tuna fishery management in the Banda Sea was the curve of the relative first length capture $\left(\mathrm{L}_{c} / \mathrm{L}_{\infty}\right)$ as function of relative fishing mortality $\mathrm{F}$ to natural mortality $\mathrm{M}$, and the yield curve per recruit relative to the theoretical and biomass maximumyield per recruit relative to unexploited biomass as a function of the $\mathrm{F} / \mathrm{M}$ ratio for different lengths at first catch. Lc_opt was analyzed by using MS Excel worksheets according to Froese et al. (2016).

\section{RESULTS AND DISCUSSION}

\subsection{Size Structure}

The size of yellowfin tuna caught during the annual period was distributed in the range of $25-178 \mathrm{~cm}$ (Fig. 2). Fish catches were dominated at the frequency of 98.5 cmlength mode.

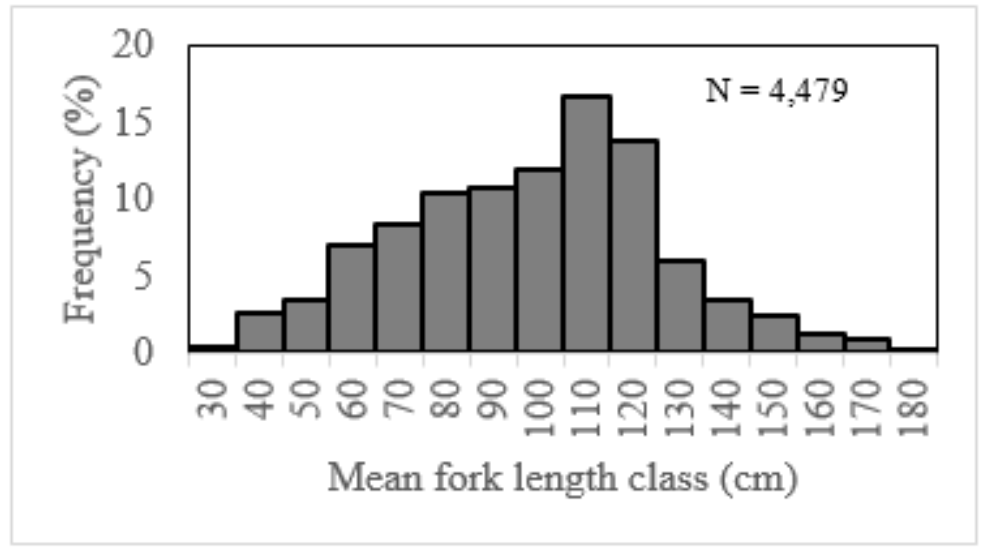

Fig. 2. Size Structure of Yellowfin Tuna Caught by Line Fishing in Banda Sea Until November 2015 to October 2016

\subsection{Growth, Mortality and Maturity}

Based on the equation ofgrowth parameters by von Bertalanffy, it was obtained growth rate coefficient $(\mathrm{K})=$ 0.31 per year, asymptotic length $\left(\mathrm{L}_{\infty}\right)=$ $215 \mathrm{~cm}$,theoreticalage of yellowfin tuna when the length is zero $\left(t_{0}\right)=-0.311$. Maximum estimated age of yellowfin tuna was 9.37 years. Total mortality (Z) was 1.47 per year and the rate of natural mortality (M) was 0.49 peryear, and the fishing mortality (F) was 0.98 per year.

The observation toward 629 samples of female gonads includingGonad Maturity Level IV which was distributed in a size range of $69-178 \mathrm{~cm}$ was obtained the first mature gonad size (length at first maturity $\mathrm{L}_{\mathrm{m}}$ ) was $103.6 \mathrm{~cm}$, and the average size of a decent catch $\left(\mathrm{L}_{50}\right)$ was $115.2 \mathrm{~cm}$. The accumulation percentage of fish catches towards a decent size of yellowfin tuna fishing in the waters of the Banda Sea amounted to $23.09 \%$.

\subsection{First length Catch}

Each fishing mortality has relationship with the first caught which will maximize the yield of stocks in a given period (Beverton and Holt, 1957, 1966). Fishing mortality (F) of yellowfin tuna in the Banda Sea from November 2015 until Oktober 2016 was 2.0 M. The length of first caught $\left(\mathrm{L}_{\mathrm{c} \_ \text {opt }}\right)$ of yellowfin tuna for fishing mortality 2.0 $M$ was $125.2 \mathrm{~cm}$, whereas $L_{c_{-} \text {opt }}$ was $117.4 \mathrm{~cm}$ for $\mathrm{F}=\mathrm{M}$ and $109.5 \mathrm{~cm}$ for $\mathrm{F}=0.5 \mathrm{M}($ Figure 2).In fishing mortality (F) level is equal to natural mortality (M), the first catch (L__opt) was 54,5\% from $\mathrm{L}_{\text {o. }}$. To meet option 1 proposed by Froese et al (2016), F should be smaller than $\mathrm{M}$, and to meet option 3, F=M in which Lc_opt is bigger than the length where yellowfin tuna has reached gonad maturity (Fig.3). 


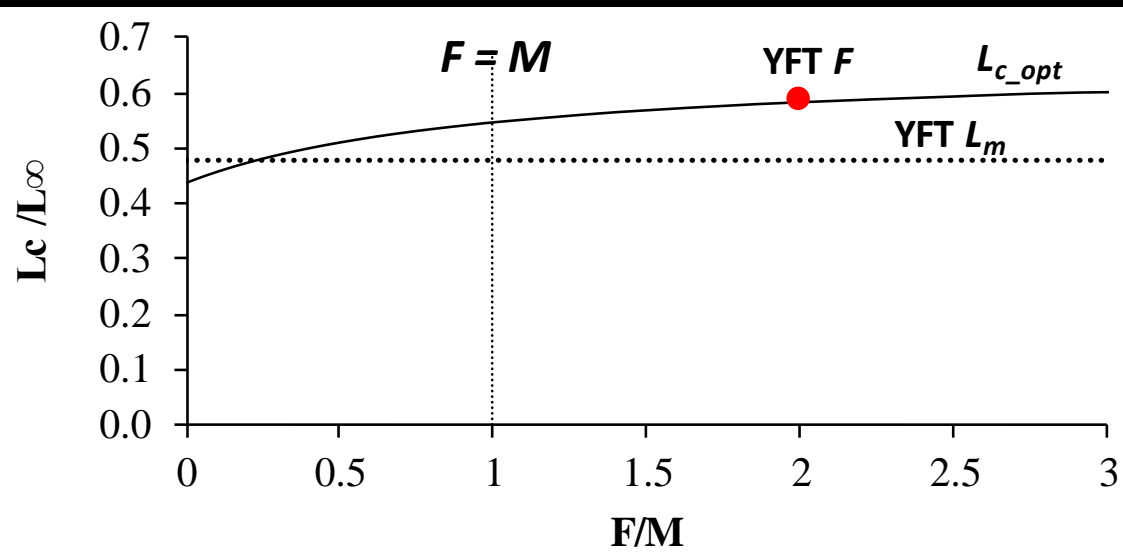

Fig. 3. The Relative First Caught Length $\left(L_{c} / L_{\infty}\right)$ of Relative Fising Mortality F to Natural Mortality M. the Doted Curve (Lc_Opt) was the Length of First Caught.Lm Indicates the Length in Whichthe Yellowfin Tuna Reaches Gonad Maturity, and Red Round Color Indicates the Actual Fishing Mortality During the Period November 2015 toOctober 2016.

3.4. Yield and Biomass per Recruit

Fig.4 is a relative yield per recruit toward theoretical yield per recruit as a function of the ratio $\mathrm{F} / \mathrm{M}$ for the first time caught length (L__opt) which were different. It shows that theincreasing of fishing mortality will cause the relative yield per recruit to the theoretical yield per recruit increasing to $\mathrm{L}_{\mathrm{c}_{-} \text {opt. }}$. If the length size of caught yelowfin tuna is with no size limit (dashed line), relative yield per recruit toward the theoretical yield per recruit for Lc_optreaches the maximum at $\mathrm{F} / \mathrm{M}=0.6$, the increasing of F/M then the relative yield per recruit of the theoretical yield per recruit for $L_{c \_o p t}$ is diminishing (Fig. 4).

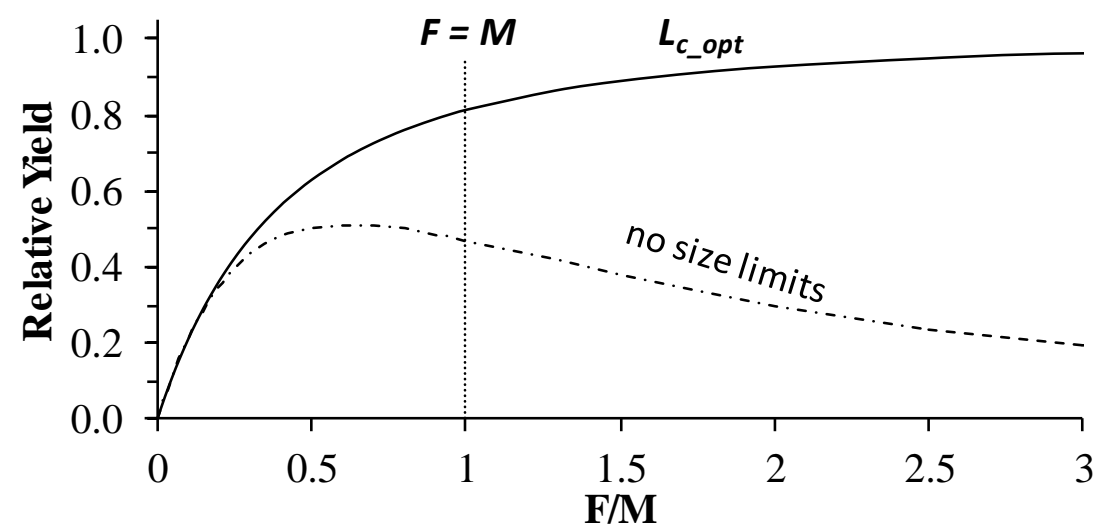

Fig. 4. The Relative Yield per Recruit to the Theoretical Maximum Yield as a Function of the F/M Ratio, for Different Lengths at first Catch of Yellowfin Tuna in Banda Sea. Lc_Opt (Solid Line) and No Size Limit (Dotted Line).

Sea (red round mark in Fig. 5) is below $\mathrm{B}=0.5 \mathrm{~B} 0$, to meet the second option then the biomass per recruit relative to the unexploited biomass for $\mathrm{L}_{\mathrm{c}_{-} \text {opt }}$ is at $\mathrm{F} / \mathrm{M}=$ 0. 8 (bold line indicated in Fig. 5). Thus, the catch pressure by $80 \%$ is equivalent to the natural death rate marking the highest theoretical fishing pressure that still meet the 3 proposed options in managing the yellowfin tuna fishery in the Banda Sea. 


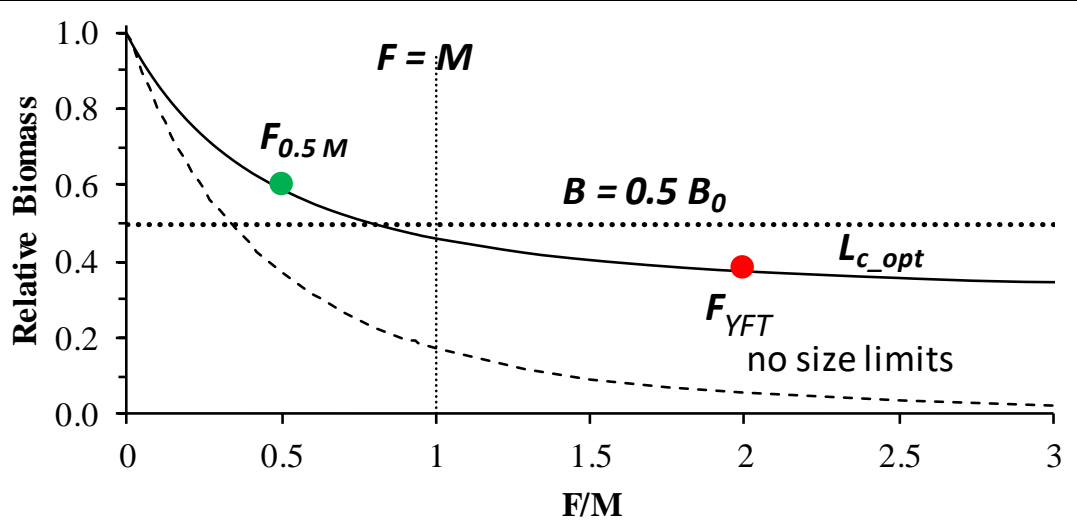

Fig. 5. Biomass per Recruit Relative to Unexploited Biomass, as a Function of the F/M Ratio, for Different Lengths at first Catch of Yellowfin Tuna in Banda Sea.

From this research, the average size of yellowfin tuna caught in the Banda Sea was $98.5 \mathrm{~cm}$. This size was still below the size of gonad first mature. Therefore for the benefit of tuna fishery management in the Banda Sea, the minimum size that must be landed needs to get attention with a regulation from the government. This is needed to be done in order to meet the substance of minimizing the impact of tuna fishing in the Banda Sea.

\section{CONCLUSION}

To minimize the catch impact of yellowfin tuna in the Banda Sea, the catching pressure with no feasible size requires attention by providing a regulation of the minimum size that can be landed. This is needed to be done so that fishing mortality becomes smaller than natural mortality.

\section{REFERENCES}

[1] Beverton RJH and SJ Holt., 1957. On the dynamics of exploited fish populations. Great Britain Ministry of Agriculture Fisheries and Food, London.

[2] Brouwer S, G Pilling, JHampton, P Williams and S McKechnie., 2016. The Western and Central Pacific Ocean: 2015 Overview and status of stocks. Tuna Fisheries Assessment Report No. 16. The Pacific Comunity Oceanic Fisheries Programe: 39 p.

[3] Charnov E. 1993. Life history invariants: some explorations of symmetry in evolutionary ecology. Oxford University Press, Oxford.

[4] Damora Aand Baihaqi., 2013. Size distribution and population parameters of yellowfin tuna Thunnus albacares in Banda Sea. Bawal Vol. 3 (1): p59-65.

[5] Davies N, S Harley, J Hampton, and S McKechnie., 2014. Stock assessment of yellowfin tuna in the Western and Central Pacific Ocean. Scientific Committee Tenth Regular Session June 2014, WCPFC: $119 p$.
[6] Fox W.W., 1970. An Exponential Surplus-Yield Model for Optimizing Exploited Fish Populations. Transactions of the American Fisheries Society 99: p80 -88.

[7] Froese B.R., 2006. Cube law, condition factor and weight - length relationships : history, meta-analysis and recommendations. Journal of Applied Ichthyology 22, 241-253.

[8] Froese B.R, H Winker, D Gascuel, UR Sumaila and D Pauly., 2016. Minimizing the impact of fishing. Fish and Fisheries: p 1-11.

[9] Froese R, A Stern-Pirlot, H Winker and D Gascuel., 2008. Size matters: how single-species management can contribute to ecosystem-based fisheries management. Fisheries Research 92: p 231-241.

[10] Gayanilo F.C. Jr., P. Sparre and D. Pauly., 1996. FAO-ICLARM Stock Assessment Tools (FiSAT) user's Guide. FAO Computerised Information Series (Fisheries). No. 8. Rome, FAO, 266p.

[11] Hampton J, P Kleiber, A Langley and K Hiramatsu., 2004. Stock assessment of yellowfin tuna in the western and central Pacific Ocean. SCTB17 Working Paper: 74p.

[12] Haruna, Mallawa A., Musbir, Zainuddin M., 2018 Population dynamic indicator of the yellowfin tuna Thunnus albacares and its stock condition in the Banda Sea, Indonesia. AACL Bioflux 11(4):13231333.

[13] IOTC., 2018. Implementation of IOTC Conservation and Management Measures - Part A: Understanding IOTC and the international fisheries management framework. Seychelles, FAO. 80 pp

[14] Itano, D. G., 2001. The Reproductive biology of yellowfin tuna (Thunnus albacares) in Hawaiian waters and the Western Tropical Pacific Ocean Yellowfin Research Group-SCTB 14 Noumea, New Caledonia, $12 \mathrm{pp}$. 
[15] Langley A, S Hoyle, and J Hampton., 2011. Stock assessment of yellowfin tuna in Western adn Central Pacific Ocean. WCPFC-SC7-2011/SA- WP-03: 132p.

[16] Langley A, M Herrera and J Million., 2012. Stock assessment of yellowfin tuna in the Indian Ocean using MULTIFAN-CL. IOTC-2012-WPTT1: 72p.

[17] Pauly D., 1980. A Section of Simple Mthod for the Assessment Tropical Fish Stock. FAO. Fish Tech. New York.

[18] Schaefer MB., 1954. Some aspects of the dynamics of populations important to the management of the commercial marine fisheries. Inter-American Tropical Tuna Commission Bulletin 1: p26-55.

[19] Sparre, P, E. Ursin and S.C. Venema., 1989. Introduction to tropical fish stock assessment. Part I. Manual. FAO, Rome. 337 p.

[20] Udupa, K.S., 1986. Statistical method of estimating the size at first maturity in fishes. Fishbyte 4 (2): 810.

[21] Widodo AA, RTh Mahulette, and F Satria., 2015. Stock status, exploitation and the management option of tuna resources in Banda Sea. Indonesian Fisheries Policy Journal, Vol. 7 No. 1: p 45-54. 